\title{
Changes in Agri-Business Outcomes among the Dairy Beneficiaries of Contracted Extension Service Delivery Model in Kenya
}

Http://dx.doi.org/10.4314/jae.v20i1.5

\author{
Bebe Bockline Omedo \\ Research and Extension Division, Egerton University P. O. Box 536-20115, Egerton, Kenya. \\ Email: obebeb@yahoo.com \\ Phone: +254721853999 \\ Mwangi John Gowland \\ Research and Extension Division, Egerton University P. O. Box 536-20115, Egerton, Kenya. \\ Email: mwangijg5@yahoo.com \\ Phone: +254723466733
}

\section{Ozor Nicholas}

African Technology Policy Studies Network (ATPS), P.O. Box 10081-00100, Nairobi, Kenya Email: nozor@atpsnet.org

Phone: +254713161928

\section{Abstract}

This study compared changes in uptake of agri-business practices, productivity and wealth creation between dairy beneficiaries and nonbeneficiaries of Contracted Extension Service Delivery Model (CESDM) implemented by Kenya Agricultural Productivity and Agribusiness Project (KAPAP) in selected counties of Kenya since 2010. Results showed a large increase in the proportion of beneficiaries accessing extension services from private service providers and expressing satisfaction with CESDM, attaining higher dairy productivity in milk and in gross margins per animal per year. However, there was only a marginal increase in willingness to pay or paying for the services and the majority of beneficiaries continued to sell milk through informal market outlets. On aggregate, CESDM posted positive net benefits and multiplicative economic power with the best performing dairy chains multiplying every shilling invested 4 to 46 times. On average, beneficiaries earned KES 4993 per farmer at a cost of KES 353 for services, inputs and equipment. We conclude that CESDM can be a viable and rewarding approach for delivering extension services to smallholder farmers but it is necessary to strengthen farmer cooperative societies because those paying for private services are still too few to sustain remunerative private sector investment in extension service delivery.

Keywords: Dairy value chain; private extension service provision; benefit-cost ratio; Quasi-experimental design; Kenya. 
Creative commons User License: CC BY-NC-ND

Abstracted by: EBSCOhost, Electronic Journals Service (EJS),

Google Scholar, Directory of Open Access Journals (DOAJ),

Journal Seek, Scientific Commons,

Food and Agricultural Organization (FAO), andCABI
Journal of Agricultural Extension

Vol. 20 (1) June, 2016

ISSN(e): 24086851; ISSN(Print); 1119944X

http://journal.aesonnigeria.org

http://www.ajol.info/index.php/jae

Email: editorinchief@aesonnigeria.org

\section{Introduction}

In Kenya, the delivery of agricultural extension services has largely been a public good. Government investments in extension services are for improving service delivery to enable farmers to access and put into use new knowledge, skills and technologies. At the farmer level, the acquired knowledge, skills and information about the technologies is an output whilst the technology adopted is an outcome and its impact is the change in productivity, income or food security situation. The evaluation of benefits of extension services to beneficiaries is at the outcome and impact levels (Spielman, 2008; White, 2009). Most of the impact evaluations of extension programme in Africa report positive and significant impacts, but the results are disputed because agricultural production and productivity has over the years remained stagnant (Taye, 2013). This reflects challenges in impact evaluation of extension interventions, which includes failure to control for extraneous factors, design effects and estimating the counterfactual conditions. Applying quasiexperimental design is one approach to have rigor in design and quantification of changes attained with the intervention (Barahona, 2010; Davis et al., 2010).

Extension service delivery in Kenya is however undergoing paradigm shift with government encouraging private sector participation to grow and sustain demanddriven extension service delivery. For instance, in 2010 the Kenya Agricultural Productivity and Agribusiness Project (KAPAP) launched Contracted Extension Service Delivery Model Approach (CESDM) in selected counties but in value chains that were selected by farmers. Under this model, farmers contract extension services from consortia of service providers whom they pay from the grants managed by them.

Service providers flag-off agribusiness opportunities to trigger demand-driven agribusiness extension services then they mobilize interested farmers to join farmer business groups (Common Interest Groups (CIGs) that are nurtured into formal cooperative societies. The payment to service providers for their professional services is in four trances starting with an initial $10 \%$, followed by $20 \%, 30 \%$ and finally $40 \%$ of the service fee based on attainment of negotiated and agreed benchmark outcomes. The beneficiaries manage the grants and they must endorse outcomes to authorize the payments for services rendered. This is an innovation integrated in the service delivery to correspond with progressive wealth creation by the beneficiaries.

\section{Purpose of the Study}

By design, the objective of the model was to enable beneficiaries to create wealth from increased productivity, value addition and linking producers to reliable and 
Creative commons User License: CC BY-NC-ND

Abstracted by: EBSCOhost, Electronic Journals Service (EJS),

Google Scholar, Directory of Open Access Journals (DOAJ),

Journal Seek, Scientific Commons,

Food and Agricultural Organization (FAO), andCABI
Journal of Agricultural Extension

Vol. 20 (1) June, 2016

ISSN(e): 24086851; ISSN(Print); 1119944X

http://journal.aesonnigeria.org

http://www.ajol.info/index.php/jae

Email: editorinchief@aesonnigeria.org

stable markets. This paper therefore examined whether the contracted service delivery model after four years of implementation had demonstrable changes in agribusiness practices, productivity and wealth creation among the beneficiaries in dairy value chains.

\section{Methodology}

The study applied quasi-experimental design to assess the changes in agri-business practices, productivity and wealth creation and food security status from household's perspective that may be associated with the implementation of CESDM and specifically in the dairy value chains. Households were randomly sampled in a stratified cross-sectional survey. Stratification was by model beneficiaries (control and intervention) selected in representative ecological zones within a county to account for diversity of farming systems, socio-economic characteristics and the value chains. The intervention sample at the inception of the model comprised those who had selfselected into the value chains. The performance of the intervention sample obtained in 2010 at the inception of the model was therefore the baseline sample performance. The control sample were constructed from within the project area on the criteria that the location of residence was not currently implementing the model, household was not a direct beneficiary of the model and the location was reasonably far from the intervention sample but shared similarities in farming and agro ecological characteristics.

A random sample of 2547 households was obtained in the ratio of $6: 4$ for the intervention $(n=1475)$ and control $(n=1065)$ samples from across agro-ecological zones within a county to account for the diversity of farming systems, socio-economic characteristics and value chains. Fifteen out of the 20 counties implementing the model were randomly sampled (Table 1 ).

Table 1: Counties sampled and those not sampled with their corresponding representative Counties

\begin{tabular}{|c|c|c|c|c|c|}
\hline Sampling & Counties & & & & \\
\hline \multirow[t]{3}{*}{ Sampled Counties } & Garissa & Tana River & Kwale & Taita Taveta & Makweuni \\
\hline & Kisii & Nakuru & Nyandarua & Nyeri & Meru \\
\hline & Busia & Siaya & Kakamega & Transnzoia & West Pokot \\
\hline $\begin{array}{l}\text { Counties not } \\
\text { sampled }\end{array}$ & Wajir & Kilifi & Homa-bay & Butere-Mumias & Embu \\
\hline $\begin{array}{l}\text { Representative } \\
\text { county for those not } \\
\text { sampled }\end{array}$ & Garissa & Kwale & Siaya & Kakamega & Meru \\
\hline
\end{tabular}


The model was evaluated with quantitative and qualitative data obtained from the household survey complemented with project database, Focus Group Discussions (FGDs) and key informant interviews. The data were analysed at three levels: household, value chain and stakeholder levels. Analysis performed compared the intervention with control and the baseline samples.

\section{Results and Discussion}

\section{Design and implementation of the contracted extension service delivery model}

To be a beneficiary of the contracted extension service delivery model (CESDM), a farmer has to register with a farmer business group. Figure 1 illustrates the features of CESDM in which farmer group receives and manages the grants from the project to pay for contracted services and receive co-financing to purchase equipment and inputs for value chain development. The feature of CESDM is demand-or marketdriven model where the farmer group pays to support development of functioning market which is important for service provision and transformation of CIGs into cooperative societies is incorporated for sustainability (Wongtschowski et al., 2013).

The model funding agency (KAPAP) facilitated service provision by building the capacity of service providers and availed grants to farmer groups and monitored attainment of the agreed set target outcomes. While service providers earned fees for their professional services, the individual farmers within a group earned incomes from their enterprise. 

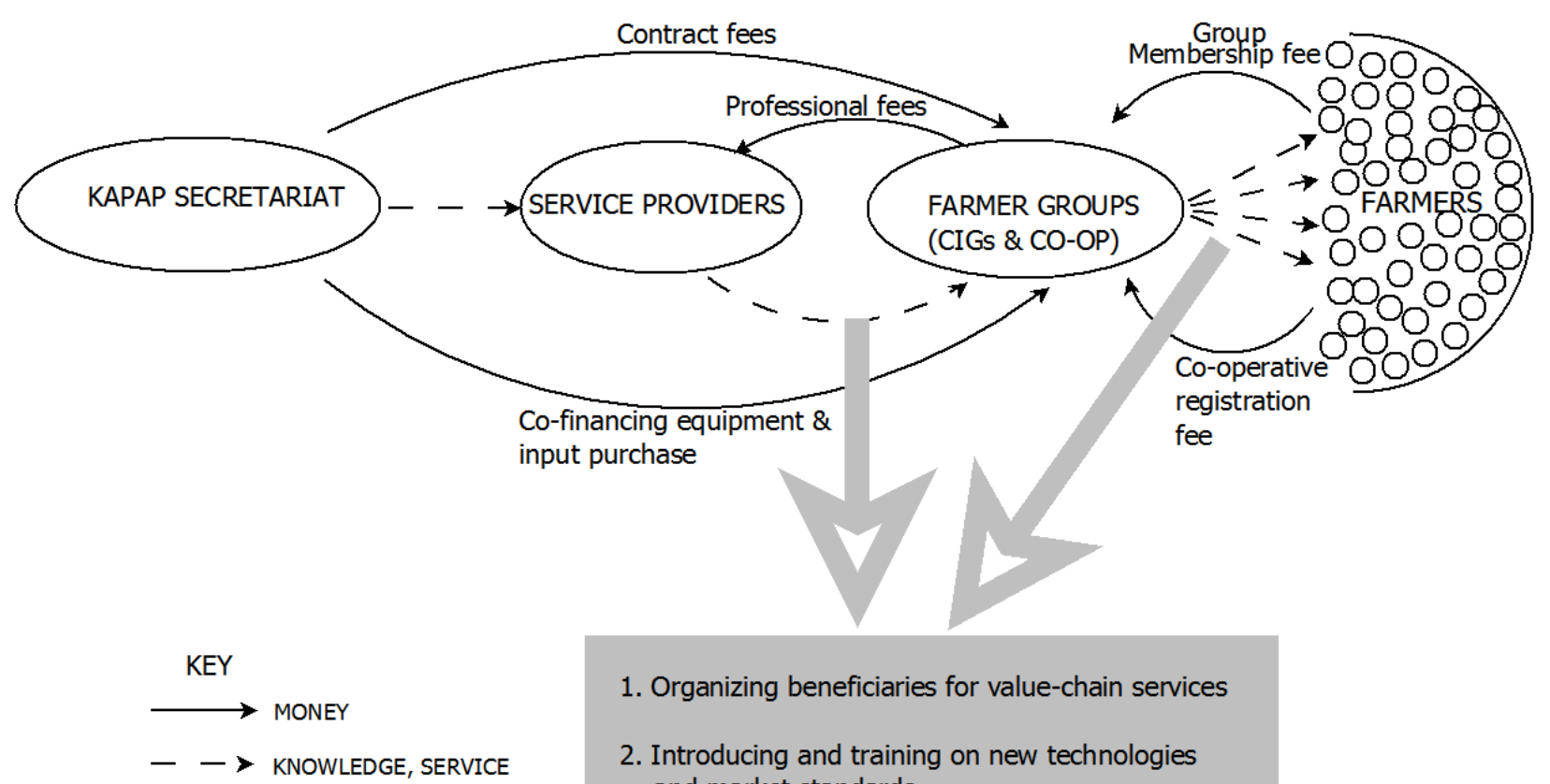

1. Organizing beneficiaries for value-chain services

2. Introducing and training on new technologies and market standards

3. Linking farmers to input, credit and market facilities

4. Transforming CIGs into Co-operative societies

\section{Figure 1: The Contracted extension service delivery model (CESDM) implemented by Kenya agricultural productivity and agribusiness project.}

\section{Changes in Accessing Contracted Extension Services}

Household survey results show that the implementation of CESDM resulted in a large increase in the proportion of beneficiaries accessing extension services from private service providers (Table 2). Compared to baseline and control samples, there was an increase in proportion of intervention sample accessing services from service providers (40 to $70 \%$ ), input dealers (10 to $49 \%$ ), and processors (60 to $75 \%$ ) and from research (53 to $75 \%$ ) while they reduced in proportion accessing services from public extension ( 45 to $15 \%$ ). This provides evidence that the model was effective in mobilising, sensitising and empowering the beneficiaries to seek demand-driven extension services to shift away from supply-driven extension services. 
Table 2: Percentage change in sourcing of extension services among sample farmers

\begin{tabular}{llllll}
\hline Sample & $\begin{array}{l}\text { Public } \\
\text { extension }\end{array}$ & Research & Processors & $\begin{array}{l}\text { Input } \\
\text { dealers }\end{array}$ & $\begin{array}{l}\text { Service } \\
\text { providers }\end{array}$ \\
\hline Baseline & 45.5 & 3.5 & 7.8 & 6.8 & 5.8 \\
$\begin{array}{l}\text { Control } \\
\text { Intervention }\end{array}$ & 75.6 & 25.5 & 22.6 & 45.6 & 35.7 \\
\% Change & 30.3 & 78.6 & 82.5 & 55.8 & 75.5 \\
Intervention vs Baseline & & & & & \\
Intervention vs Control & -15.2 & 75.1 & 74.7 & 49.0 & 69.7 \\
\hline
\end{tabular}

Compared with base and control samples (Table 3), the intervention sample showed an increase from 17 to $63 \%$ in those expressing satisfaction with contracted service delivery, but only a marginal increase of $4 \%$ in those willing to pay or are paying for contracted services. A large proportion of farmers $(\geq 75 \%)$ expressed willingness to pay for contracted services but only a few were already paying for contracted services $(\leq 11 \%)$ and therefore percentage change in those willing to pay or are paying for contracted services is marginal (3.9\%). This suggests that farmers find difficulties at individual level to pay for extension services and implies organizing farmers in cooperatives will be necessary for sustaining demand for contracted services. A previous study by Ozor et al. (2013) also reported that majority of farmers in Nigeria (95.1\%) were willing to pay for improved extension services irrespective of their poor income status so long as the extension services remained relevant to their felt needs. In a similar study, Chukwuone et al. (2006) found out that one of the most effective strategies through which farmers can pay for the cost of private extension services is through the farmers' cooperative societies.

Table 3: Percentage change in proportion of farmers satisfied, willing to pay, or are paying for contracted extension services by sample farmers

\begin{tabular}{llll}
\hline Sample & Satisfied with services & $\begin{array}{l}\text { Willing to pay for } \\
\text { services }\end{array}$ & Pays for services \\
\hline Base & 26.2 & - & \\
Control & 71.4 & 74.7 & 7.1 \\
Intervention & 88.7 & 78.6 & 10.7 \\
\% Change & & & - \\
Intervention vs Base & 62.5 & - & 3.9 \\
Intervention vs Control & 17.3 & 3.9 & \\
\hline
\end{tabular}

Figure 2 illustrates the frequency of contracted extension services that farmers ranked top three most effective for value chain development. In order of decreasing importance, these were training (48\%), formation of CIGs (25\%), market access 
(15\%), formation of cooperatives (13\%) and business proposal development (10\%). These responses points to high value that farmers attach to building their capacity in knowledge, skills and technology as well as building supportive business institutions and entrepreneurial skills, which can enhance their capacity to innovate (Kilelu et al., 2014).

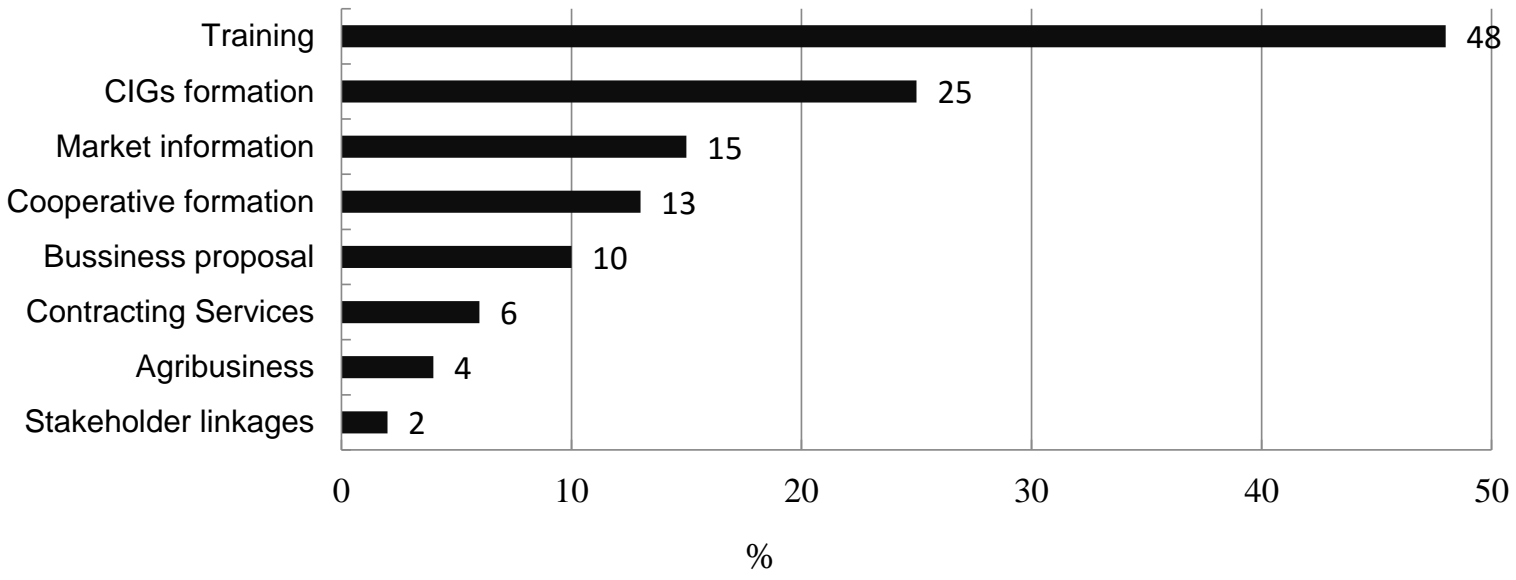

Figure 2: Effective interventions in decreasing order of importance expressed by sample farmers

\section{Changes in Dairy Productivity}

Compared to control household sample, intervention households attained higher dairy productivity by about 6 per cent in milk production and 62 per cent in gross margins per animal per year (Table 4). The gains realised by the model beneficiaries above their base and control sample counterparts would suggest that provision of demand-driven services enabled farmers to better access knowledge, skills and technologies and remunerative market prices which corroborates with the implementation of model (Figure 1). Change in productivity is an important outcome to provide for marketed surplus milk for income to grow wealth, which is in line with the goal in agri-business intervention. In agribusiness, access to market for input and output provide incentive to adopt innovations, which contribute to improved productivity as observed by Amankwah et al., (2012) in analysis of innovation systems for market participation northern Ghana. 
Table 4: Change in milk production and gross margins by sample farmers participating in the contracted extension services

\begin{tabular}{lll}
\hline Sample & $\begin{array}{l}\text { Milk } \\
\text { (kg/cow/year) }\end{array}$ & $\begin{array}{l}\text { Gross margins } \\
\text { (KES/cow/year) }\end{array}$ \\
\hline Base & 1020 & \\
Control & 2922 & 11615 \\
Intervention & 3087 & 18909 \\
\% Change & & \\
Intervention vs Base & 202.6 & \\
Intervention vs Control & 5.6 & 62.8 \\
\hline
\end{tabular}

\section{Changes in Milk Marketing}

Results presented in Table 5 show that majority of the intervention sample farmers still prefer to sell milk in the informal market outlets (15 to $46 \%$ ) to traders and neighbours rather than in the formal market outlets (3 to 23\%) to cooperatives, processors or hotels. Following the implementation of CESDM, the beneficiaries selling milk to cooperatives increased (by 4 to $13 \%$ ) but there was a decrease among those selling milk to traders (13\%), processors (1 to $5 \%$ ) or to a gain farmer cooperative (nKCC) (2 to $5 \%$ ) when compared to base and control samples. This would suggest that CESDM is progressively encouraging more farmers to participate in the formal milk market outlets mainly through formation of cooperatives.

Table 5: Percentage (\%) changes in farmers' participation in milk market outlets

\begin{tabular}{|c|c|c|c|c|c|c|}
\hline Sample & nKCC & Processors & Cooperatives & $\begin{array}{l}\text { Hotels \& } \\
\text { institutions }\end{array}$ & Traders & Neighbours \\
\hline Base & 7.7 & 10.6 & 10.0 & 6.0 & 27.6 & 38.1 \\
\hline Control & 5.6 & 6.5 & 19.3 & 6.2 & 14.1 & 48.4 \\
\hline Intervention & 3.2 & 5.7 & 23.3 & 7.4 & 15.1 & 46.3 \\
\hline $\begin{array}{l}\% \text { Change } \\
\text { Intervention }\end{array}$ & & & & & & \\
\hline $\begin{array}{l}\text { vs Base } \\
\text { Intervention }\end{array}$ & -4.5 & -4.9 & 13.3 & 1.4 & -12.5 & 8.2 \\
\hline vs Control & -2.4 & -0.8 & 4.0 & 1.2 & 1.0 & -2.1 \\
\hline
\end{tabular}

Despite being trained in new technologies, only a few farmers had been trained in milk value addition and therefore adoption of milk value addition is very low probably due to lack of specialised equipment for milk value addition (Table 6). New partnerships and strategies developed jointly with other actors such as County Governments and NGOs were initiated to purchase value addition equipment that could be pooled for use by the beneficiaries. This demonstrates partnership building in actor platform, which is not always able to adapt adequately to challenging issues, in this case uptake of value addition (Kilelu et al., 2014). Therefore, intervention 
Creative commons User License: CC BY-NC-ND

Abstracted by: EBSCOhost, Electronic Journals Service (EJS),

Google Scholar, Directory of Open Access Journals (DOAJ),

Journal Seek, Scientific Commons,

Food and Agricultural Organization (FAO), andCABI
Journal of Agricultural Extension

Vol. 20 (1) June, 2016

ISSN(e): 24086851; ISSN(Print); 1119944X

http://journal.aesonnigeria.org

http://www.ajol.info/index.php/jae

Email: editorinchief@aesonnigeria.org

actions are necessary to strengthen institutions for learning and adaptive management to facilitate innovation process.

Table 6: Changes in farmers trained in and practicing milk value addition among the sample farmers

\begin{tabular}{lll}
\hline Sample & $\begin{array}{l}\text { Trained in milk value } \\
\text { addition }\end{array}$ & $\begin{array}{l}\text { Adding value to } \\
\text { milk }\end{array}$ \\
\hline Base & 1.2 & 6.6 \\
Control & 2.2 & 5.7 \\
Intervention & 1.1 & 4.7 \\
\% Change & & \\
Intervention vs Base & -0.1 & -1.9 \\
Intervention vs Control & -1.1 & -1.0 \\
\hline
\end{tabular}

\section{Wealth Creation}

Table 7 presents the benefits to beneficiaries and the costs of implementing contracted extension service delivery by dairy values and the aggregate for all value chains. Analysis uses data for the period between 2010 when the model was implemented to December 2014 at the time the model was evaluated. At the model aggregate, the Benefit Cost Ratio (BCR) shows that every shilling invested in contracting extension services generated KES 15.2 while Return on Investment (ROI) show that every invested shilling was multiplied 14 times. For the dairy value chains, best performing ones multiplied every shilling invested 4 to 46 times, implying that implementation of the model was associated with positive net benefits and multiplicative economic power and therefore contracted extension services can be viable. This enabled beneficiary to earn wealth, which at the model aggregate was KES 4993 a farmer at a cost of KES 353 for services, inputs and equipment. Some dairy value chains performed above the model aggregate in wealth created per farmer, earning as high as KES 10376 to 77450 at a cost of KES 1125 to 1922 for services, inputs and equipment. The large differences in value chain economic performance may be related to leadership and management capacities of the farmer groups because each group set their own outcome benchmarks on basis of baseline performance levels.

The returns on investment were in the range of 4 to $46 \%$, which are within 5 to $50 \%$ reported in extension programmes in developing countries by the World Bank (Alex et al, 2002). A meta-analysis of 289 studies found a median return on investment rate of 58 per cent for extension investment and 36 percent on extension and research combined (Alston et al., 2000). These analyses conclude that extension targeting technologies for intensification are viable interventions for realising sustainable productivity increases and emphases on application of knowledge and related information, skills, technologies, and attitudes to foster success of rural development investments. 
Table 7: The benefit cost ratio, return on investment and cost per farmer served in implementing the contracted extension service delivery in dairy value chains

\begin{tabular}{lrrrr}
\hline County & $\begin{array}{r}\text { Benefit Cost } \\
\text { Ratio (KES) }\end{array}$ & $\begin{array}{r}\text { Return on } \\
\text { Investment (KES) }\end{array}$ & $\begin{array}{r}\text { Cost per farmer } \\
\text { served (KES/farmer) }\end{array}$ & $\begin{array}{r}\text { Earnings } \\
\text { (KES/farmer) }\end{array}$ \\
\hline Kakamega & 46 & 45 & 682 & 31057 \\
WestPokot & 40 & 39 & 1922 & 77450 \\
Nyeri & 21 & 20 & 226 & 4779 \\
TaitaTaveta & 9 & 8 & 1125 & 10376 \\
Meru & 5 & 4 & 146 & 705 \\
Makueni & -52 & -53 & 274 & -14091 \\
Nakuru & -61 & -62 & 644 & -39195 \\
TransNzoia & -87 & -88 & 131 & -11421 \\
Nyandarua & -100 & -101 & 220 & -22092 \\
Kilifi & -180 & -181 & 435 & -78132 \\
Kisii & -219 & -220 & 342 & -74881 \\
& & & & \\
Model overall & 15 & 1415 & 353 & 4993 \\
\hline
\end{tabular}

\section{Changes in Household Food Security}

From the household survey data, a comparison was made by samples for the proportion of households that expressed experiencing food security during the year. Figure 3 presents the results. Compared to control households sample, the intervention sample had more households experiencing food security in most months of the year, which is evidence that participation in the model enabled a household to attain increased farm productivity and subsequently attain improved food security situation. The change in food security can be partly associated with positive change in dairy productivity that was observed among the intervention sample (Table 4) as farmers could have adequate milk for family consumption and surplus to market for income with which they can buy other crop farm inputs or food stuffs that the household may need. The committee on world food security (CFS, 2013) has recommended that investing in smallholder agriculture for food and nutrition security pays in stimulating economic development. 


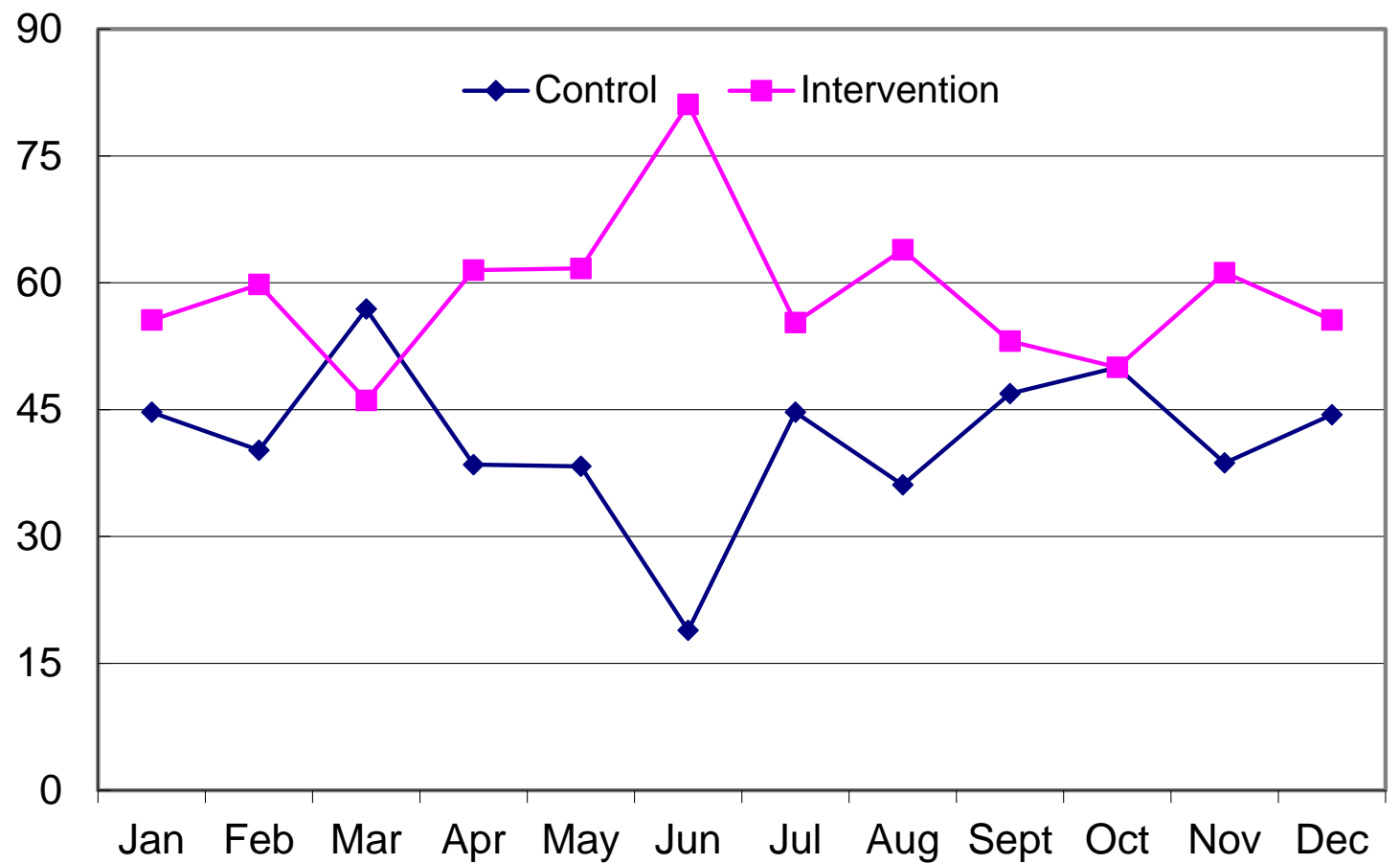

Figure 1: Percentage (\%) households by sample expressing that they are food secure during the year

\section{Conclusion and Recommendations}

The main objective of the model was to create wealth from increased productivity, value addition and linking producers to reliable and stable markets. This study has provided evidence that contracted extension service delivery can bring positive desirous changes in agri-business practices, productivity and wealth creation as well as household food security among the beneficiaries. The findings demonstrate that contracted extension services can be a viable and rewarding approach to delivering extension services to smallholder farmers. However, to encourage private sector participation to grow and sustain demand-driven extension service delivery will require strengthening farmer institutions such as cooperative societies through which farmers can contract for priority services that they need and make checkoff payments at the cooperative level rather than at individual farmer level. This is because smallholder farmers paying for private delivered extension services are still too few to sustain remunerative private sector investment in extension services. In strengthening farmer cooperatives, attention should be paid to enabling them attain a critical mass/volume of production in order that they secure and sustain reliable markets for sustainable incomes/ profits for both the households and cooperatives. It is desirous for the cooperative leaders and managers that they institutionalize the Quality Management System and Governance in their entities to ensure continuous 
improvement, effective service delivery and accountability to their members to retain and grow membership numbers and confidence.

\section{References}

Amankwah K., L Klerkx, S.J. Oostings, O Sakyi-Dawson, A.J. vander Zijpp, D Miller. 2012. Diagnosing constraints to market participation of producers in northern Ghana:: Innovation systems analysis. NJAS-Wageningen Journal of Life Sciences. 60:63: 37-47.

Alex, Gary, Willem Zijp, Derek Byerlee, 2002. Rural Extension and Advisory Services: New Directions. Rural Development Strategy Background Paper \#9. Washington, D.C.: Agriculture \& Rural Development Department, World Bank.

Alston J., C Chan-Kang, M. Marra, P. Pargey, T Wyatt. 2000. A meta-analysis of rates of return to agricultural R\&D. Ex Pede Harculum? Research Report 113 of IFPRI, Washington.

Barahona, C. 2010. Randomised control trials for the impact evaluation of development initiatives: statistician's point of view. ILAC working paper 13. Rome, Italy. Institutional learning and change initiatives.

Chukwuone N.A., A.E. Agwu and N. Ozor. 2006. Constraints and strategies toward effective cost-sharing of agricultural technology delivery in Nigeria. Journal of International Agricultural and Extension Education, Texas A\&M USA,Vol. 13(1): 29-41. Available at: http://www.aiaee.org/attachments/145 Chukwuone$\underline{\text { Vol-13.1-4.pdf }}$

Committee on world food security, 2013. Policy recommendations on investing in smallholder agriculture for food security and nutrition.

file:///D:/Consultancy/Chapaters/CFS 40 investing in smallholders for\%20fo od\%20security.pdf . Accessed on 18 ${ }^{\text {th }}$ May, 2016.

Davis, K., Nkonya, E., Kato, E., Mekonnen, M., Odendo, M., Miiro, R. \&Nkuba, J. 2010. 'Impact of farmer field schools on agricultural productivity and poverty in East Africa', IFPRI Discussion Paper 00992, International Food Policy Research Institute, Washington, DC, viewed 27 August 2013, from http://www.ifpri.org/sites/default/ files/publications/ifpridp00992.pdf 
Creative commons User License: CC BY-NC-ND

Abstracted by: EBSCOhost, Electronic Journals Service (EJS),

Google Scholar, Directory of Open Access Journals (DOAJ),

Journal Seek, Scientific Commons,

Food and Agricultural Organization (FAO), andCABI
Journal of Agricultural Extension

Vol. 20 (1) June, 2016

ISSN(e): 24086851; ISSN(Print); 1119944X

http://journal.aesonnigeria.org

http://www.ajol.info/index.php/iae

Email: editorinchief@aesonnigeria.org

Kilelu,C. W., L. Klerkx \& C. Leeuwis. 2014. How dynamics of learning are linked to innovation support services: Insights from a smallholder commercialization project in Kenya. The Journal of Agricultural Education and Extension, 20:2, 213-232, DOI: 10.1080/1389224X.2013.823876

Ozor, N., C.J. Garforth, and M.C. Madukwe. 2013. Farmers' willingness to pay for agricultural extension service: Evidence from Nigeria. Journal of International Development Vol. 25 Issue 3: 382-392; DOI: 10.1002/jid.1849. Available online at: http://onlinelibrary.wiley.com/doi/10.1002/jid.1849/abstract

Taye, H. 2013. Evaluating the impact of agricultural extension programmes in subSaharan Africa: Challenges and prospects'. African Evaluation Journal 1(1), Art. \#19, 9 pages. http://dx.doi.org/10.4102/ aej.v1i1.19

Spielman, D. 2008. Encouraging economic growth in Ethiopia: Perspectives on agricultural input markets, agricultural extension and advisory services, and agricultural education and training.

http://users. ox.ac.uk/ econstd/Brief_DSpielman.pdf

White, H. 2009. 'Some Reflections on Current Debates in Impact Evaluation', Working Paper 1, International Initiative for Impact Evaluation, New Delhi.

Wongtschowski M., J. Belt, W. Heemskerk, D. Kahan (ed). 2013. Royal Tropical Institute, Amsterdam; Food and Agriculture Organisation, Rome; AgriProfocus, Arnhem. page 15. 